\title{
The Effects of Covid-19 on the Competitiveness of Touristic Business in Yucatan
}

\author{
Antonio Emmanuel Pérez Brito, ${ }^{1, *}$ Laura Guillermina Duarte Cáceres ${ }^{2}$, Martha Isabel \\ Bojórquez Zapata ${ }^{2}$ \\ ${ }^{I}$ Facultad de Contaduría y Administración. Universidad Autónoma de Yucatán. Calle 19 \# $186 \times 24$ \\ Fraccionamiento Jardines Miraflores C.P. 97168, Mérida, Yucatán, México \\ ${ }^{2}$ Facultad de Contaduría y Administración. Universidad Autónoma de Yucatán
}

\begin{abstract}
*Corresponding Author: Antonio Emmanuel Pérez Brito, 1Facultad de Contaduría y Administración. Universidad Autónoma de Yucatán. Calle 19 \# 186 x 24 Fraccionamiento Jardines Miraflores C.P. 97168, Mérida, Yucatán, México
\end{abstract}

\begin{abstract}
The aim of this study is to identify the effects of coronavirus on the competitiveness of touristic businesses in Yucatan, Mexico. Competitiveness is a multitude of factors and policies that promote the creation of increased value for business and society without negatively impacting the environment. For this article the preferred methodology was the revision of relevant literature from a wide variety of authors. In terms of conclusions it was found that companies that invest in strategic, operative and financial resilience to emergent global risks will be better placed to ensure competitiveness.
\end{abstract}

Keywords: Coronavirus, competitiveness, business, tourism, Yucatan.

\section{INTRODUCTION}

The International Labour Organization (ILO, 2020) reported that from January to June 2020 international tourism suffered a global downturn of $65 \%$ triggering the loss of 440 million international arrivals and approximately 460 million dollars of revenue. The Mexican state of Yucatan - where tourism represents $10.1 \%$ of state GDP (INEGI, 2014) - has been one of the destinations affected by Covid-19. Economic reactivation has been slow and is yet to take effect in many branches of tourism. A survey conducted with tourism service providers within the state towards the end of September indicated that $45.2 \%$ percent of businesses remained closed, $9.0 \%$ of employed personnel have been dismissed and economic losses of \$2,078.4 million Mexican pesos are estimated for the period March - September 2020 (SEFOTUR, 2020).

In terms of air, land and sea passenger transport, the first two have seen a slow recovery, however the docking of cruise ships into Yucatan's main port is still suspended and this negatively affects economic activity in the region (SEFOTUR, 2020).

Yucatan has been one of the Mexican states where containment strategies have been most energetic and this attempt to protect citizens has had obvious repercussions for the economy. However, it is also important to consider the numerous support packages which the government has provided to the business sector and the general population during the height of the Covid-19 pandemic.

\section{DEVELOPMENT}

\subsection{Competitiveness}

According to Blunck (2006), competitiveness is the ability to provide products and services more effectively and efficiently than the competition. In the commercial sector this means sustained success in international markets without protection or subsidies. Competitiveness at the industrial level is a better indicator for the economic health of nations that compete via businesses.

For Garelli (2007), it is the competitive environment of nations that ensures the competitiveness of businesses and created wellbeing. Pohl (2007) suggests that focusing on the discovery of new talent, identifying new roles for company finances and creating new reference points via the financial directorship will allow companies to be competitive in modern markets. 
Perea and Rivas (2008) concluded a study on competitiveness in the Veracruz coffee industry by asserting that the factors which have the greatest influence on competitiveness are:

Innovation, Marketing, Finances

Pisano and Shih (2009) establish that the only way to be competitive is by maintaining advantages in innovation over the long term, and the only way to achieve this is by investing in newdifferentiated capabilities.

According to Malhotra and Manyika (2011), for businesses to be competitive it is necessary for federal, state and local governments to effectively tackle the barriers that impede growth and productivity by supporting business innovation.

For Castellanos and Ramirez (2020) it is the systemic capacity of the nation, its sectors, its regions, its businesses and/or its individuals - across all dimensions - to achieve maximum exploitation of resources, value generation, elevation of living standards and relevant knowledge within the population which will give rise to the establishment of differentiation in the marketplace under particular conditions, and thereby ensure development.

\subsection{Coronavirus and its Effect on Businesses}

For Cifuentes (2020), the Covid-19 pandemic is an unprecedented crisis which makes comparisons with previous global crises difficult. The real economy, that made up of businesses and workers, is bearing the brunt. This crisis is affecting every country from economic superpowers to developing nations. We are seeing an erosion of both supply and demand, and financial markets are in freefall, causing many businesses to fail, especially in retail and tourism sectors.

The same author states that in all countries it will be the service sector that suffers the most severe effects, owing to the imposition of travel restrictions and the forced closure of many retail and hospitality establishments. The buying and selling of goods will be unfeasible if related services - like transportation - are not being offered. Unlike with goods, with services it is not possible to withdraw inventories today only to reintroduce them later, meaning commercial losses in service sectors during this health and economic crisis are largely irrecuperable.

In addition to the grave consequences of coronavirus in terms of human health, Madrid and Diaz (2020) propose that the effects on global tourism will also be considerable, they claim it is not unrealistic to suggest that the economic damage will be the worst the industry has seen since World War II

\section{DISCUSSION}

Several authors like Garelli, Blunk, Perea, Rivas, Castellanos and Ramirez have highlighted the importance of factors such as decision-making and action within organizations, management, innovation, production and human resources to competitiveness. Competitiveness in a business is associated with concepts like profitability, productivity, costs, added value, market share, export levels, technological innovation, product quality among others. Other indicators can also be found such as labor productivity and capital productivity among others.

\section{Results}

Early data for the probable impact on the tourism industry is alarming and highlights the need for structured public policies that strengthen the sector during the difficult months to come, in order to safeguard jobs and mitigate reduce losses. The World Tourism Organization (UNWTO, 2020) has established that this year world tourism income streams could fall between $1 \%$ and $3 \%$ which translates as a shortfall in world economic revenue of between 20 and 50 billion dollars in 2020. In the case of air travel, the International Air Travel Association (IATA) estimates that losses in the aviation sector will be somewhere between 63 and 113 billion dollars over the year.

A moderate estimate for the impact on Mexico's tourism GDP for 2020 sits in the range of 0 and $1.0 \%$; in a second scenario where the impact could be considered intermediate, the drop could be in the range of $-1.0 \%$ and $-3.0 \%$, and in a third scenario which anticipates a severe impact, the reduction could be between $-3.0 \%$ and $-5.0 \%$ and remain in the red throughout 2021 (UNWTO, 2020).

According to Yucatan's Tourism Development Secretariat (SEFOTUR, 2020), the negative economic effects from the Covid-19 pandemic will continue to affect the tourism sector of the state. Destination management companies (DMCs) in particular remain under temporary suspension of operations. During the period from March to December of the current year, representatives from nine DMCs in 
Yucatan estimated in interviews that economic losses could total $\$ 101.4$ million pesos as a result of the cancelation or postponement of at least 91 large scale events with 17,416 attendees, $75 \%$ of whom were to travel from within Mexico and 25\% from abroad.

Furthermore, the Covid-19 health crisis continues to disrupt operations with regard to national and international flights arriving into Mexico City's International Airport.

\section{CONCLUSiOnS}

Beyond the concerns relating to future business operability, employee protection and market preservation; businesses and indeed countries must re-examine their exposure the complex and evolving interdependencies that could exacerbate the effects to pandemics and other crises. Given the cycle of panic and lack of preparedness for a pandemic, once Covid-19 is contained it is likely that a degree of complacency will return, and the world may once again be caught by surprise by an inevitable future outbreak. Businesses that invest in strategic, operational and financial resilience to emerging global risk will find themselves much better placed to be competitive enough to both respond and recover.

\section{REFERENCES}

[1] Blunck, F. (2006). What is competitiveness? Estados Unidos. Competitiveness Summer School. 74[1], 1-32

[2] Castellanos, O. y Ramírez, D. (2020). Competitividad, Apropiación y Mecanismos para su Fortalecimiento. Colombia. Universidad Nacional de Colombia.

[3] Cifuentes, J. (2020). Crisis del Coronavirus: Impacto y Medidas Económicas en Europa y en el Mundo. Espaco e Economía. 18[9], 1-8.

[4] Garelli, S. (2007). Competitiveness of Nations. The Fundamentals. EstadosUnidos. World Competitiveness Yearbook.

[5] IATA. (2020). IATA Updates COVID-19 Financial Impacts- Relief Mesures Needed.Recopilado el 19/09/2020 de: https://www.iata.org/en/pressroom/pr/2020-03-05-01/

[6] Madrid, F. y Díaz, J. (2020). Coronavirus y Turismo. Centro de Investigación y Competitividad Turistica Anahuac. 1, 1-6

[7] Malhotra, V y Manyika, J. (2011). Five Misconceptions about the Productivity. Estados Unidos. The Mc Kinsey Quartely. 15[1], 1-3.

[8] OMT. (2020). Las Cifras de Turistas Internacionales podrían caer un 60-80\% en 2020. Recopilado el 19/09/2020 de: https://www.unwto.org/es/news/covid-19-las-cifras-de-turistas-internacionales-podriancaer-un-60-80-en-2020

[9] Perea, J., y Rivas, L. (2008) Estrategias competitivas para los productores cafetaleros de la región de Cordova, Veracruz. México. Revista de la Facultad de Contaduría y Administración de la UNAM. 24. 933

[10] Pisano, G. y Shih, W. (2009). Restoring American Competitiveness. Estados Unidos. Harvard Business Review. 80[5], 2-14.

[11] Pohl, H. (2007). Building a competitive finance function: An executive roundtable. Estados Unidos. The Mc Kinsey Quartely. 10[3], 1-8.

[12] SEFOTUR. (2020). Termómetro del Impacto al Séctor Turístico en Yucatán por la Contingencia del COVID-19. Recopilado el 09/10/2020 de: http://www.sefotur.yucatan.gob.mx/files-content/general/ d7732 c49048d56c557750ef06365b045.pdf 


\section{AUTHORS' BIOGRAPHY}
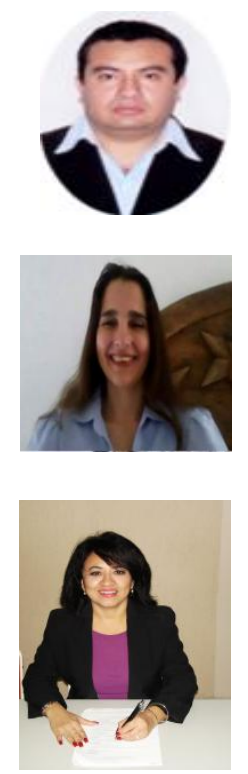

Antonio Emmanuel Perez Brito, Ph.D. from Universidad Popular Autonoma del Estado de Puebla (August 2014), is Professor of finance at the Facultad de Contaduria y Administracion of the Universidad Autonoma de Yucatan (antonio.perez@ correo.uady.mx). Current research interestsinclude competitiveness and financial management.

Laura Guillermina Duarte Cáceres, Ph,D., from Universidad del Sur (March 2013), is Professor of finance at the Facultad de Contaduria y Administracion of the Universidad Autonoma de Yucatan (guillermina.duarte@correo.uady.mx). Current research interestsinclude competitiveness and financial management.

Martha Isabel Bojorquez Zapata, Ph.D., from Universidad del Sur (March 2013), is Professor of finance at the Facultad de Contaduria y Administracion of the Universidad Autonoma de Yucatan (mbzapata@correo.uady.mx). Current research interestsinclude competitiveness and financial management.

Citation: Antonio Emmanuel Pérez Brito, et.al. "The Effects of Covid-19 on the Competitiveness of Touristic Business in Yucatan" International Journal of Managerial Studies and Research (IJMSR), vol 9, no. 1, 2021, pp. 9-12. doi: https://doi.org/10.20431/2349-0349.0901002.

Copyright: (C) 2021 Authors. This is an open-access article distributed under the terms of the Creative Commons Attribution License, which permits unrestricted use, distribution, and reproduction in any medium, provided the original author and source are credited. 